\title{
E-Ticaret Sektöründe Algılanan Lojistik Hizmet Performansı ile Marka Sadakati ve Marka Güveni Arasındaki İlişki: Meslek Yüksekokulu Öğrencileri Üzerinde Bir Araştırma
}

Berna ÇAĞLAR, İstanbul Aydın Üniversitesi, mbernacaglar@gmail.com

ÖZET

Bu çalışmada; elektronik ticaret sektöründe marka sadakati sağlamak amacıyla algılanan lojistik hizmet performansı ile markayla ilgili çeşitli yapıların arasındaki ilişki incelenmektedir. Bu amaçla; Anadolu Bil Meslek Yüksekokulu öğrencileri üzerinde kantitatif araştırma teknikleri kullanılarak araştırma yapılmıştır. Araştırma sürecinde elde edilmiş olan veriler, SPSS 21.0 paket programı ile değerlendirmeye tabi tutulmuştur. Araştırma hipotezlerinin analizinde güvenilirlik, faktör ve korelasyon analizleri kullanılmıştır. Bu araştırmanın sonucunda; elektronik ticaret sektöründe algılanan lojistik hizmet performansı ile marka sadakati ve markayla ilgili çeşitli yapıların göstergeleri arasında anlamlı ilişkilere ulaşılmıştır. Ayrıca; işletmelerin elektronik ticaret uygulamalarına ilişkin algılanan lojistik hizmet performansların arttırmaları sayesinde marka sadakati göstergelerinde elde edecekleri faydalar konusunda önerilere yer verilmiştir.

Anahtar kelimeler: Marka Sadakati, Marka Ünü, Algılanan Lojistik Hizmet Performansı

\section{The Relation Between Perceived Performance of Logistics Services in E-Commerce Sector, Brand Loyalty and Brand Trust: A Study on the Students Of Vocational School of Higher Education}

\footnotetext{
ABSTRACT This study analyses the relation between the perceived performance of logistics service to ensure brand loyalty in e-commerce sector and the various concepts of branding. For this purpose, a research has been conducted on university student in Anadolu Bil Vocational School of Higher Education by using quantitative research methods. SPPS.21.0 software is used and research hypotheses are tested with the help of reliability, correlation and factor analysis. As a result of this research, significant relations have been found between the perceived performance of logistics service of e-commerce firms and indicators of brand loyalty and various concepts of branding. Also, recommendations concerning the potential benefits firms in e-commerce sector can gain in brand loyalty indicators by increasing their perceived performance of logistics services have been included in the study.
}

Keywords: $\quad$ Brand Loyalty, Brand Reputation, Perceived Performance of Logistic Service 


\section{Giriş}

1990'lı yıllardan itibaren internet kullanımının yaygınlaşması sonucunda günümüzde farklı iş modelleri kullanılmaktadır. E-ticaret, yeni iş modellerinden biri olarak karşımıza çıkmaktadır ve tüm dünyada hızla büyümektedir. E-ticaret, doğrudan ve fiziksel bağlantı kurmaya ya da fiziksel mübadele işlemine gerek kalmadan, işletmelerinin müşteriler ile elektronik olarak iletişim kurdukları her türlü ticari iş etkinliği olarak ifade edilebileceği gibi bilgi, iki veya daha fazla taraf arasında ürün ve hizmet değişimini içeren işlemlerin elektronik araçlarla ve yöntemlerle yapılması olarak da tanımlanabilmektedir. (Yeşil, 2010: 19). İşletmeler, müşterilerini anlayabilme, kişiselleştirilmiş ürün ve hizmet sunabilme ve en önemlisi etkin bir iletişim sistemi kurarak müşteri memnuniyeti yaratma gayreti içerisindedirler. Müşteriler ile ilgili bilgi işletmeler için önem kazanmaktadır. Bu bilgilere kolay erişebilme ve anlık sorgulama yapabilme, hızlı değişen müşteri beklentilerini karşılayabilme yeteneğine e-ticaret faaliyetleri de olumlu yönde etki yapabilmektedir. Öte yandan, e-ticaret müşterilerin ihtiyaç duydukları ürünlere ve hizmetlere hızlı ve kolay bir şekilde erişmelerini sağlamaktadır. Müşteriler aynı ürün ve hizmet için internet üzerinden birçok satıcıya ulaşabilmektedir. Bu nedenle; müşteriler, e-ticaret sitelerini sundukları hizmetler bakımından birbirinden ayırmaktadır. Öyle ki; müşteriler yoğun rekabet ortamında kendileri için değer yaratan, kaliteli ve düşük maliyetli ürün ve hizmetleri tercih etmeye başlamaktadır (Odabaşı, 2010:12). Özellikle maliyet etkinliği ve yüksek müşteri memnuniyeti için, e-ticaret sitelerinin lojistik hizmetlerinde kayıp, gecikme ve hasarın en aza indirmesi, süreçlerinin ilk aşamasından itibaren işletme tarafından izlenmesi göz önüne alınması gereken unsurlar arasında bulunmaktadır. E-ticarette müşteri sadakatine katkıda bulunan bir diğer unsur ise müşterinin markaya ve işletmeye duyduğu güven olduğu söylenebilmektedir. E-ticaret sitesinin arkasındaki markanın faaliyetleri, bilinirliği, başarısı ve konumu hakkındaki bilgi tüketicinin markaya olan güvenini etkilemektedir. Marka iyi bir üne sahip değilse tüketici e-ticaret sitesine karşı daha temkinli davranmaktadır. Ayrıca tüketicinin güven duymasını zorlaştırmaktadır. (Lau \& Lee, 1999:346)

E-ticaret sitelerine sahip olan işletmeler için müşterilerle uzun dönemli ilişkiler oluşturmak gittikçe önem kazanmaktadır. Bu yüzden işletmeler, müşteri memnuniyetini sağlamayı amaç olarak belirlemektedir. İşletmelerin başarılı olabilmesi için uzun dönemde karlılığını sürdürmesi gerekmektedir. Uzun dönemde karlılığın anahtarı ise müşteri memnuniyetinden geçmektedir (Odabaş1, 2010:14). Müşteri memnuniyetine etki eden faktörler, hizmet kalitesi, fiyat ve işletmenin imajı olarak sıralanabilmektedir. Bu üç unsur, müşterinin ürün ve hizmetle ilgili değer algısını etkilemektedir. Kalite, müşteri memnuniyetini etkileyen en önemli unsurdur. Müşteri tarafından algılanan kalitenin genel memnuniyet üzerinde direkt olarak etkisi bulunmaktadır. Algılanan kalite arttıkça; müşteri memnuniyeti aynı oranda artmaktadır. Fiyat; memnuniyetin oluşmasında önemli bir rol oynamaktadır. Müşteriler, ürün ve hizmetten elde ettikleri faydayı, ödedikleri fiyat ile karşılaştırmaktadır. Bu karşılaştırma sonucunda elde ettikleri yarar fiyata kıyasla ne kadar fazla ise o düzeyde de memnuniyetleri artmaktadır. Müşteri memnuniyetinde göz önünde tutulan diğer bir unsur ise işletmenin imajıdır. İmaj kavramı içerisinde işletmenin faaliyetleri (müşteri odaklılık, inovasyon), etikleri(istikrar ve güvenilirlik, dürüstlük), kurumsal sosyal sorumlulukları yer almaktadır. İşletmenin itibarı ve tanınmışlığ 1 müşteri memnuniyetini pozitif yönde etkilemektedir (Naumann \&Giel, 1995:218). Karlı bir şekilde büyümenin en önemli 
araçlarından biri müşteriyi elde tutmak, diğer bir ifadeyle müşteri sadakati yaratmaktır. Yeni bir müşteri elde etmenin maliyetinin mevcut bir müşteriyle iş yapmanın beş katı daha yüksek olduğu artık çok iyi bilinmektedir (Arabacı, 2010:178). Tüketicinin bir markada belirleyici özellikler algılaması ve bu özelliklerden etkilenmesi, o markaya ve işletmeye duyduğu sadakatin ve inancın gücünün artmasına neden olmaktadır (Uztuğ, 2003:33).

\section{Araștırma}

Araştırmanın temel amacı; e-ticaret sitelerinden yapılan alışverişlerde marka sadakati sağlamak amacıyla algılanan lojistik hizmet performansı ile markayla ilgili çeşitli yapılar arasındaki ilişkilerin incelenmesidir. Araştırmanın anakütlesini, Anadolu Bil Meslek Yüksekokulu, Lojistik Programı öğrencileri oluşturmaktadır. Zaman ve maliyet kısıtlardan dolayı araştırmada kolayda örnekleme yöntemine başvurulmuştur. Kolayda örnekleme tesadüfi olmayan örnekleme yöntemlerinden biridir. Tesadüfi olmayan örneklemede birimlerin ana kütleden örneğe seçimi kişisel yargılara dayanır. Burada hangi elemenin örnek kütleye dahil edileceğine bilinçli olarak araştırmacı karar verir (Nakip, 2003: 182). Kolayda örnekleme yönteminde anket katılımcılarından sadece ulaşılabilir olanların örnek kapsamına dahil edilmesini içerir. Özellikle zaman ve maliyet gibi kısıtlar araştırmacıyı kolayda örneklemeye sevkeder. Son yıllarda, İnternet ortamında gerçekleştirilen ve giderek yaygınlaşan anketlerde de bu yöntem kullanılmaktadır ( Gegez,2010: 217). Araştırma kapsamına, lojistik programında öğrenimine devam eden 438 öğrenciden e-ticaret siteleri üzerinden ürün alışverişi yapan öğrenciler dahil edilmiştir. Çalışmada anket yöntemi ile veri ve bilgi toplanmıştır. 04 mart ile 2 şubat 2014 tarihleri arasında ulaşılan 356 öğrenciden toplam 130 adet anket formunun geri dönüşü sağlanmıştır. Anket formlarının 29 tanesi eksik doldurulmuş olması nedeniyle elenerek 101 adet anket formu veri girişine hazır hale getirilmiştir. Araştırma sürecinde elde edilmiş olan veriler, SPSS 21.0 paket programı ile değerlendirmeye tabi tutulmuştur. Veri ve bilgilerin analizinde güvenilirlik, faktör ve korelasyon analizleri kullanılmıştır.

Çalışmanın anketi üç bölümden oluşmaktadır. Anketin ilk bölümünde katılımcıların e-ticaret sitelerinden gerçekleştirdikleri alışverişlere ilişkin sorular bulunmaktadır. Anketin ikinci bölümü e-ticaret sitelerinin lojistik hizmet performansına ilişkin sorular içermektedir ve yedi sorudan oluşmaktadır. Anketin üçüncü bölümü ise marka sadakati, marka ünü, marka tahminlemesi ve güven değişkenleri ile ilgili sorular içermektedir ve yirmi üç sorudan oluşmaktadır. İkinci ve üçüncü bölümdeki değişkenler, beşli likert tipi ölçek ile (1: kesinlikle katılmıyorum; 5: kesinlikle katılıyorum olmak üzere) ölçülmeye çalışılmıştır.

\section{Araştırma Değişkenleri ve Modeli}

Lojistik hizmet performansı, marka sadakati ve markanın diğer boyutları üzerine literatürde çeşitli çalışmalar bulunmaktadır. Bu çalışma keşifsel bir araştırmadır. Araştırma modelinde 
marka sadakatinin, marka ünü, marka tahminlemesi, güven ve lojistik hizmet performansı ile olan ilişkisi incelenmiştir. Araştırmanın marka boyutları ile ilgili ölçeğe ait değişkenler hazırlanırken; Lau ve Lee (1999), Matzler vd. (2006) ve Babalco vd. (2012), Aaker (1996)'nin kullandığı ölçeklerden; lojistik hizmet performansının değişkenleri hazırlanırken ise Huang vd.(2007)' in kullanılan ölçekten yararlanılmıştır. Araştırma modeline uygun olarak araştırma hipotezleri Tablo 1'de görüldügü gibidir.

Tablo 1: Araştırmanın Hipotezleri

\begin{tabular}{|l|}
\hline \multicolumn{1}{|c|}{ Hipotezler } \\
\hline $\begin{array}{l}\text { H1: Lojistik Hizmet Performansı ile marka sadakati arasında bir ilişki } \\
\text { vardır. }\end{array}$ \\
\hline H2: Güven ile marka sadakati arasında bir ilişki vardır. \\
\hline H3: Marka tahminlemesi ile marka sadakati arasında bir ilişki vardır. \\
\hline H4: Marka Ünü ile marka sadakati arasında bir ilişki vardır. \\
\hline
\end{tabular}

Şekil 1: Araştırmanın Modeli

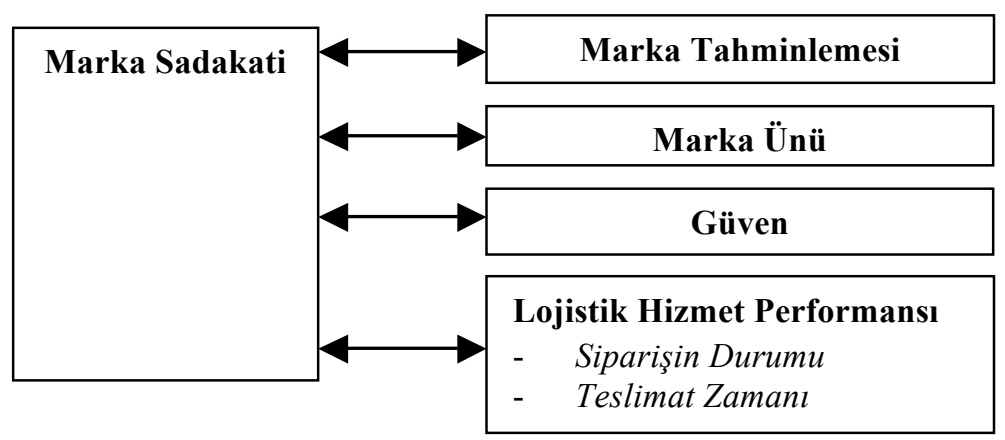

Şekil 1.'de görüldüğü gibi araştırmanın modelinde; marka sadakatinin, marka tahminlemesi, marka ünü, güven ve lojistik hizmet performansı ile olan ilişkisinin belirlenmesi amaçlanmıştır. Lojistik hizmet performansı; siparişin durumu ve teslimat zamanı olarak alt değişkenler içermektedir.

\section{Araştırmanın Bulgularının Değerlendirilmesi}

Çalışmanın bu bölümünde; frekans dağılımları, güvenilirlik analizi sonuçları, faktör analizi sonuçları, korelasyon analizi sonuçları başlıkları yer almaktadır.

\section{Frekans Dağılımları}


Tablo 2: Cinsiyet Dağılımı

\begin{tabular}{|c|c|c|c|c|}
\hline & Frekans & Yüzde & $\begin{array}{c}\text { Geçerli } \\
\text { Yüzde }\end{array}$ & $\begin{array}{c}\text { Kümülatif } \\
\text { Yüzde }\end{array}$ \\
\hline Kız & 33 & 33 & 33 & 33 \\
\hline Erkek & 68 & 67 & 67 & 100,0 \\
\hline Toplam & 101 & 100,0 & 100,0 & \\
\hline
\end{tabular}

Elde edilen bulgulara göre, araştırmaya katılan 101 öğrencinin \%33'ünü kı, \%67'ini ise erkek öğrenci oluşturmaktadır.

Tablo 3: Yaş Dağılımı

\begin{tabular}{|c|c|c|c|c|}
\hline & Frekans & Yüzde & $\begin{array}{c}\text { Geçerli } \\
\text { Yüzde }\end{array}$ & $\begin{array}{c}\text { Kümülatif } \\
\text { Yüzde }\end{array}$ \\
\hline 20 yaş ve altı & 37 & 37 & 37 & 37 \\
\hline 21 yaş - 25 yaş & 62 & 61 & 61 & 98,0 \\
\hline 26 yaş -30 yaş & 2 & 2,0 & 2,0 & 100,0 \\
\hline Toplam & 101 & 100,0 & 100,0 & \\
\hline
\end{tabular}

Elde edilen bulgulara göre, araştırmaya katılan 101 öğrencinin \%37'sı olan 37 öğrenci 20 yaş ve altında, \%61'ü olan 62 öğrenci 21 ve 25 yaş arasında, \%2'si olan 2 öğrenci ise 26 ve 30 yaş arasında olduğunu belirtmiştir.

Tablo 4: Aylık Gelir Dağılımı

\begin{tabular}{|c|c|c|c|c|}
\hline & Frekans & Yüzde & $\begin{array}{c}\text { Geçerli } \\
\text { Yüzde }\end{array}$ & $\begin{array}{c}\text { Kümülatif } \\
\text { Yüzde }\end{array}$ \\
\hline 1000 TL ve daha az & 56 & 55,4 & 55,4 & 55,4 \\
\hline 1001 TL - 2000 TL arası & 34 & 33,7 & 33,7 & 89,1 \\
\hline 2001 TL - 3000 TL arası & 4 & 4,0 & 4,0 & 93,1 \\
\hline 3001 TL - 4000 TL arası & 5 & 5,0 & 5,0 & 98,0 \\
\hline 5001 TL - 6000 TL arası & 1 & 1,0 & 1,0 & 99,0 \\
\hline 6001 TL ve üzeri & 1 & 1,0 & 1,0 & 100,0 \\
\hline Toplam & 101 & 100,0 & 100,0 & \\
\hline
\end{tabular}

Elde edilen bulgulara göre, araştırmaya katılan 101 öğrencinin \%55,4'ü olan 56 öğrenci 1000 TL ve daha az, \%33,7'si olan 34 öğrenci 1001 TL ve 2000 TL arası, \%4'ü olan 4 öğrenci 2001 TL ve 3000 TL arası, \%5'i olan 5 öğrenci 3001 TL ve 4000 TL arası, \%1'i olan 1 öğrenci 5001 TL ve 6000 TL arası, \%1'i olan 1 öğrenci ise 6001 TL ve üzeri aylık gelire sahip olduğunu belirtmiştir. 
Tablo 5: Son 1 ay için Internet Üzerinden Yapılan Alışveriş Tutarı

\begin{tabular}{|l|l|l|l|l|}
\hline & Frekans & Yüzde & $\begin{array}{l}\text { Geçerli } \\
\text { Yüzde }\end{array}$ & $\begin{array}{l}\text { Kümülati } \\
\text { f Yüzde }\end{array}$ \\
\hline 250 TL ve alt1 & 70 & 69,3 & 69,3 & 69,3 \\
\hline 251 TL - 500 TL aras1 & 18 & 17,8 & 17,8 & 87,1 \\
\hline 501 TL - 750 TL aras1 & 4 & 4,0 & 4,0 & 91,1 \\
\hline 751 TL - 1000 TL aras1 & 2 & 2,0 & 2,0 & 93,1 \\
\hline 1001 TL - 1250 TL aras1 & 1 & 1,0 & 1,0 & 94,1 \\
\hline 1251 TL - 1500 TL aras1 & 1 & 1,0 & 1,0 & 95,0 \\
\hline 1501 TL ve üzeri & 5 & 5,0 & 5,0 & 100,0 \\
\hline Toplam & 101 & 100,0 & 100,0 & \\
\hline
\end{tabular}

Elde edilen bulgulara göre, araştırmaya katılan 101 öğrencinin \%69,3'ü olan 70 öğrenci 250 TL ve altı, \%17,8'i olan 18 öğrenci 251 TL ve 500 TL arası, \%4'ü olan 4 öğrenci 501 TL ve 750 TL arası, \%2'si olan 2 öğrenci 751 TL ve 1000 TL arası, \%1'i olan 1 öğrenci 1001 TL ve 1250 TL arası, \%1'i olan 1 öğrenci ise 1251 TL ve 1500 TL arası, \%5'i olan 5 öğrenci ise 1501 TL ve üstü tutarda son 1 ay için internet üzerinden alışveriş yaptığını belirtmiştir.

Tablo 6: En Sık Alışveriş Yapılan E-Ticaret Siteleri

\begin{tabular}{|l|l|l|l|l|}
\hline & Frekans & Yüzde & $\begin{array}{l}\text { Geçerli } \\
\text { Yüzde }\end{array}$ & $\begin{array}{l}\text { Kümülatif } \\
\text { Yüzde }\end{array}$ \\
\hline www.markafoni.com & 21 & 20,7 & 20,7 & 20,7 \\
\hline www.trendyol.com & 13 & 12,8 & 12,8 & 33,5 \\
\hline www.gittigidiyor.com & 9 & 8,9 & 8,9 & 42,4 \\
\hline www.morhipo.com & 7 & 6,9 & 6,9 & 49,3 \\
\hline www.yemeksepeti.com & 7 & 6,9 & 6,9 & 56,2 \\
\hline www.hepsiburada.com & 7 & 6,9 & 6,9 & 63,1 \\
\hline www.sahibinden.com & 7 & 6,9 & 6,9 & 70 \\
\hline Diğerleri & 30 & 29,7 & 29,7 & 100 \\
\hline Toplam & 101 & 100,0 & 100,0 & \\
\hline
\end{tabular}

Elde edilen bulgulara göre araştırmaya katılan 101 öğrencinin en sık alışveriş yaptıkları eticaret siteleri arasında ilk sirada www.markafoni.com, ikinci sirada www.trendyol.com, üçüncü sırada ise www.gittigidiyor.com e-ticaret siteleri bulunmaktadır.

\section{Güvenilirlik Analizleri Sonuçları}

$\mathrm{Bu}$ bölümde, araştırmada yer alan ölçeklerin güvenilirlik analizi sonuçlarına yer verilmektedir. 
Tablo 7: Lojistik Hizmet Performansını Ölçmek Amacıyla Hazırlanan Ölçeğin Güvenilirlik Analizi Sonucu

\begin{tabular}{|r|r|}
\hline \multicolumn{2}{|c|}{ Güvenilirlik İstatistikleri } \\
\hline Cronbach Alfa Katsayıs1 & Değişken Sayısı \\
\hline, 720 & 7 \\
\hline
\end{tabular}

Tablo 8: Marka Sadakati, Marka Ünü, Müşteri Tahminlemesini ve Güveni Ölçmek Amaciyla Hazırlanan Ölçeğin Güvenilirlik Analizi Sonucu

\begin{tabular}{|r|r|}
\hline \multicolumn{2}{|c|}{ Güvenilirlik İstatistikleri } \\
\hline Cronbach Alfa Katsayısı & Değişken Sayıs1 \\
\hline, 943 & 23 \\
\hline
\end{tabular}

E-ticaret sitelerinin lojistik hizmet performanslarını ölçmek amacıyla hazırlanan 7 adet değişkenden oluşan ölçeğe ait Cronbach Alfa Katsayısı; 0,72'dir. E-ticaret sitelerinin marka sadakati, marka tahminlemesi, marka ünü ve güveni ölçmek amacıyla hazırlanan ve 23 adet değişkenden oluşan ölçeğe ait Cronbach Alfa Katsayısı; 0,943'tür. Söz konusu değerlerin her ikisi de, genel kabul gören 0,70 değerinin üzerindedir. Her iki ölçeğe ait güvenilirlik analizi bulgularından hareketle, ölçeklerin içsel tutarlılıklarının tatminkar oldukları görülebilmektedir.

\section{Araştırma Değişkenlerine Ait Faktör Analizi Sonuçları}

E-ticaret sitelerinin lojistik hizmet performansı ile marka sadakati, marka ünü, güven ve marka tahminlemesini ölçmek için hazırlanan ölçeklerdeki fazla olan değişken sayılarının veri indirgemesinin yapılması amacıyla sırasıyla 7 ve 23 değişken faktör analizine tabi tutulmuştur. Böylelikle; elde edilecek veriler daha anlaşılır ve yorumlanabilir olmaktadır.

Tablo 9: Lojistik Hizmet Performansını Ölçmek Amacıyla Hazırlanan Ölçeğin KMO ve Bartlett Testi Sonucu

\begin{tabular}{|l|l|}
\hline $\begin{array}{l}\text { Kaiser-Meyer-Olkin } \\
\text { Örnekleme Yeterliliği Testi }\end{array}$ & 0,775 \\
\hline Bartlett Küresellik Testi & $\mathrm{X}^{2}=127,394$ \\
& $\mathrm{df}=21$ \\
& Sig $=0,00$ \\
\hline
\end{tabular}

Faktör analizi sonucunda Kaiser-Meyer-Olkin (KMO) örnekleme yeterliliği istatistiği ve Bartlett Küresellik İstatistiği sonucu Tablo 9'da verilmiştir. Bu istatistik testi; örnekleme 
yeterliliği ölçmeye yarar ve örneklem büyüklüğü ile ilgilenir. KMO bir oran olup, \%60'ın üstünde olması arzulanır (Nakip, 2003: 409). Değerler incelendiğinde Kaiser-Meyer-Olkin (KMO) katsayısı 0,775 olarak hesaplanarak örneklemin faktör analizi için yeterli olduğu görülmüştür. Barlett küresellik testi sonucu ise 127,394 olarak belirlenmiştir. Bu değer, 0,00 anlamlılık düzeyinde geçerlidir. Bartlett küresellik testi sonucuna göre ise değişkenler arasında faktör analizi yapmaya yeterli düzeyde bir ilişki bulunduğu anlaşılmaktadır (Nakip, 2003: 409). Bu iki testin sonucuna göre faktör analizine devam edilmiştir.

Tablo 10: Lojistik Hizmet Performansını Ölçmek Amacıyla Hazırlanan Ölçeğe İlişkin Faktör Analizi Sonuçları

\begin{tabular}{|l|l|c|c|}
\hline \multicolumn{1}{|c|}{ DEĞIŞKEN } & $\mathbf{1}$ & $\mathbf{2}$ \\
\hline $\mathbf{X 8}$ & Siparişler uygun bir ambalaja sahiptir. & $\mathbf{0 , 8 0 2}$ & \\
\hline X7 & Siparişler doğru teslim edilir. & $\mathbf{0 , 7 5 8}$ & \\
\hline X1 & $\begin{array}{l}\text { Bu e-ticaret sitesinden siparişlerin güncel teslimat bilgilerine } \\
\text { ulaşıllabilir. }\end{array}$ & $\mathbf{0 , 5 1 0}$ & \\
\hline X4 & Siparişler hasarsı teslim edilir. & $\mathbf{0 , 5 0 3}$ & \\
\hline X6 & Bu e-ticaret sitesinde stok problemi yaşanmaz. & & $\mathbf{0 , 7 8 3}$ \\
\hline X2 & Sipariş verme ve teslim alma arasında geçen süre kisadır. & & $\mathbf{0 , 7 8 0}$ \\
\hline X3 & Siparişler söz verilen tarihte teslim edilir. & $\mathbf{0 , 6 6 0}$ \\
\hline
\end{tabular}

Yukarıdaki Tablo 10'dan da görüldüğü üzere, faktör analizi sonucunda toplam 2 faktör elde edilmiştir. Bu faktörlerin toplam açıklanan varyansı \%54,030 olarak tespit edilmiştir. Faktör analizi sonucunda elde edilen 2 faktör aşağıda belirtildiği şekilde isimlendirilmiştir;

FAKTÖR 1: SIPARIŞ่IN DURUMU: Bu faktör altında 4 değişken bulunmaktadır. Faktör yükü en yüksek olan değişken; 'Siparişler uygun bir ambalaja sahiptir' değişkenidir (Faktör yükü: 0,802). Faktör yükleri incelendiğinde, faktör altında yer alan değişkenlerin e-ticaret sitelerinin sipariş yönetimi ile ilişkili olduğu görülmektedir. Buna göre; bu faktöre 'Siparişin Durumu' ismi verilmiştir. Bu faktörün açılanan varyans yüzdesinin \%39,101 olduğu tespit edilmiştir.

FAKTÖR 2: TESLIMAT ZAMANI: Bu faktör altında 3 değişken bulunmaktadır. Faktör yükü en yüksek olan değişken; 'Bu e-ticaret sitesinde stok problemi yaşanmaz'değişkenidir (Faktör yükü: 0,783). Faktör yükleri incelendiğinde, faktör altında yer alan değişkenlerin siparişlerin teslimat zamanı ile ilişkili olduğu görülmektedir. Buna göre; bu faktöre 'Teslimat Zamanı' ismi verilmiştir. Bu faktörün açıklanan varyans yüzdesinin \%14,929 olduğu tespit edilmiştir. 
E-Ticaret Sektöründe Algılanan Lojistik Hizmet Performansı ile Marka Sadakati ve Marka Güveni Arasındaki ilişki: Meslek Yüksekokulu Öğrencileri Üzerinde Bir Araştırma

Tablo 11: Marka Sadakati, Marka Ünü, Müşteri Tahminlemesini ve Güveni Ölçmek Amacıyla Hazırlanan Ölçeğin KMO ve Bartlett Testi Sonucu

\begin{tabular}{|l|l|}
\hline $\begin{array}{l}\text { Kaiser-Meyer-Olkin } \\
\text { Örnekleme Yeterliliği Testi }\end{array}$ & 0,901 \\
\hline Bartlett Küresellik Testi & $\mathrm{X}^{2}=1433,236$ \\
& $\mathrm{df}=231$ \\
& Sig $=0,00$ \\
\hline
\end{tabular}

Faktör analizi sonucunda Kaiser-Meyer-Olkin (KMO) örnekleme yeterliliği istatistiği ve Bartlett Küresellik İstatistiği sonucu Tablo 11'de verilmiştir. Bu istatistik testi; örnekleme yeterliliği ölçmeye yarar ve örneklem büyüklüğü ile ilgilenir. KMO bir oran olup, \%60'in üstünde olması arzulanır (Nakip, 2003: 409). Değerler incelendiğinde Kaiser-Meyer-Olkin (KMO) katsayısı 0, 901 olarak hesaplanarak örneklemin faktör analizi için yeterli olduğu görülmüştür. Barlett küresellik testi sonucu ise 1433,236 olarak belirlenmiştir. Bu değer, 0,00 anlamlılık düzeyinde geçerlidir. Bartlett küresellik testi sonucuna göre ise değişkenler arasında faktör analizi yapmaya yeterli düzeyde bir ilişki bulunduğu anlaşılmaktadır (Nakip, 2003: 409). Böylelikle, bu iki testin sonucuna göre faktör analizine devam edilmiştir.

Tablo 12: Marka Sadakati, Marka Ünü, Müşteri Tahminlemesini ve Güveni Ölçmek Amacıyla Hazırlanan Ölçeğe İlişkin Faktör Analizi Sonuçları

\begin{tabular}{|c|c|c|c|c|c|}
\hline DEĞ & ŞKEN & 1 & 2 & 3 & 4 \\
\hline $\mathbf{X} 22$ & Bu e-ticaret sitesi müşterilerine karş1 dürüsttür. & $\mathbf{0 , 8 3 3}$ & & & \\
\hline $\mathbf{X 2 1}$ & Bu e-ticaret sitesi verdiği söz ve taahhütleri yerine getirir. & 0,748 & & & \\
\hline $\mathbf{X 2 3}$ & Bu e-ticaret sitesi etik davranmaktadır. & 0,715 & & & \\
\hline X14 & Bu e-ticaret sitesi istikrarlı bir performansa sahiptir. & 0,662 & & & \\
\hline $\mathbf{X 2 0}$ & Bu e-ticaret sitesi müşteri odaklıdır. & 0,652 & & & \\
\hline $\mathbf{X} 24$ & Bu e-ticaret sitesinin beni aldatmayacağına inanıyorum. & 0,642 & & & \\
\hline $\mathbf{X} 25$ & $\begin{array}{l}\text { Bu e-ticaret sitesinden alışveriş yaptığımda beni hayal } \\
\text { kırıklığına uğratacağı endişesini duymuyorum. }\end{array}$ & $\mathbf{0 , 5 9 9}$ & & & \\
\hline $\mathbf{X} 27$ & $\mathrm{Bu}$ e-ticaret sitesine tamamiyla güvenebileceğimi & 0,593 & & & \\
\hline $\mathbf{X 1 8}$ & $\begin{array}{l}\text { Bu e-ticaret sitesi ihtiyaçlarımı diğerlerine göre daha iyi } \\
\text { karşılamaktadır. }\end{array}$ & 0,472 & & & \\
\hline $\mathbf{X 3 0}$ & Bu e-ticaret sitesini başkalarına tavsiye ederim. & & $\mathbf{0 , 7 6 7}$ & & \\
\hline $\mathbf{X 3 1}$ & $\begin{array}{l}\text { Bu e-ticaret sitesinin iyi olduğunu yakın çevremle sıklıkla } \\
\text { paylaşıyorum. }\end{array}$ & & 0,712 & & \\
\hline $\mathbf{X} 28$ & Bu e-ticaret sitesinden alışveriş yapmaya devam edeceğim. & & 0,627 & & \\
\hline $\mathbf{X 1 6}$ & Bu e-ticaret sitesi sektöründe en iyisidir. & & 0,596 & & \\
\hline $\mathbf{X 1 7}$ & $\begin{array}{l}\text { Bu e-ticaret sitesi diğerlerine göre daha iyi performans } \\
\text { sergilemektedir. }\end{array}$ & & $\mathbf{0 , 5 5 5}$ & & \\
\hline $\mathbf{X} 26$ & Bu e-ticaret sitesine güveniyorum. & & $\mathbf{0 , 5 5 1}$ & & \\
\hline
\end{tabular}




\begin{tabular}{|l|l|l|c|c|}
\hline $\mathbf{X 1 5}$ & $\begin{array}{l}\text { Bu e-ticaret sitesi her zaman beklentimi karşıllayan bir } \\
\text { performans sergiliyor. }\end{array}$ & & $\mathbf{0 , 7 7 4}$ & $\mathbf{0 , 6 2 4}$ \\
\hline $\mathbf{X 1 3}$ & $\begin{array}{l}\text { Bu e-ticaret sitesinin performansının nasıl olacağı hakkında } \\
\text { her zaman doğru tahminde bulunabiliyorum. }\end{array}$ & & $\mathbf{0 , 6 1 5}$ & \\
\hline $\mathbf{X 1 9}$ & Bu e-ticaret sitesi müşterileri ile içtenlikte ilgilenmesi ile & & $\mathbf{0 , 4 8 0}$ & \\
\hline $\mathbf{X 2 9}$ & $\begin{array}{l}\text { Biri bu e-ticaret sitesi hakkında olumsuz yorum yaparsa } \\
\text { savunurum. }\end{array}$ & & & $\mathbf{0 , 7 9 9}$ \\
\hline $\mathbf{X 1 1}$ & Bu e-ticaret sitesi iyi performans göstermesi ile ünlenmiştir. & & & $\mathbf{0 , 7 1 8}$ \\
\hline $\mathbf{X 9}$ & Bu e-ticaret sitesi iyi olması ile ünlüdür. & & $\mathbf{0 , 6 9 7}$ \\
\hline $\mathbf{X 1 2}$ & $\begin{array}{l}\text { Bu e-ticaret sitesinden ürün satın aldığımda tam olarak nasıl } \\
\text { bir tecrübe yaşayacağımı biliyorum. }\end{array}$ & & & \\
\hline
\end{tabular}

Yukarıdaki Tablo 12'den de görüldüğü üzere, faktör analizi sonucunda toplam 4 faktör elde edilmiştir. Bu faktörlerin toplam açıklanan varyansı \%64,824 olarak tespit edilmiştir. Faktör analizi sonucunda elde edilen 4 faktör aşağıda belirtildiği şekilde isimlendirilmiştir;

FAKTÖR 1: GÜVEN : Bu faktör altında 9 değişken bulunmaktadır. Faktör yükü en yüksek olan değişken; 'Bu e-ticaret sitesi müşterilerine karşı dürüsttür.'değişkenidir (Faktör yükü: 0,833). Faktör yükleri incelendiğinde, faktör altında yer alan değişkenlerin işletmeye duyulan güven ile ilişkili olduğu görülmektedir. Buna göre; bu faktöre 'Güven' ismi verilmiştir. Bu faktörün açılanan varyans yüzdesinin \%46,967olduğu tespit edilmiştir.

FAKTÖR 2: MARKA SADAKATİ: Bu faktör altında 6 değişken bulunmaktadır. Faktör yükü en yüksek olan değişken; 'Bu e-ticaret sitesini başkalarına tavsiye ederim'değişkenidir (Faktör yükü: 0, 0,767). Faktör yükleri incelendiğinde, faktör altında yer alan ve en yüksek faktör yükü olan değişkeni dikkate alınarak; bu faktöre 'Marka Sadakati' ismi verilmiştir. Bu faktörün açıklanan varyans yüzdesinin \%6,955 olduğu tespit edilmiştir.

FAKTÖR 3: MARKA TAHMINLEMESİ: Bu faktör altında 4 değişken bulunmaktadır. Faktör yükü en yüksek olan değişken; 'Bu e-ticaret sitesi her zaman beklentimi karşılayan bir performans sergiliyor 'değişkenidir (Faktör yükü: 0,774). Faktör yükleri incelendiğinde, faktör altında yer alan ve en yüksek faktör yükü olan değişkeni dikkate alınarak; bu faktöre 'Marka Tahminlemesi' ismi verilmiştir. Bu faktörün açılanan varyans yüzdesinin \%5,583 olduğu tespit edilmiştir.

FAKTÖR 4: MARKA ÜNÜ: Bu faktör altında 3 değişken bulunmaktadır. Bu değişkenlerden faktör yükü en yüksek olan değişken; 'Bu e-ticaret sitesi iyi performans göstermesi ile ünlenmiştir' değişkenidir (Faktör yükü: 0, 799). Faktör yükleri incelendiğinde, faktör altında yer alan ve en yüksek faktör yükü olan değişkeni dikkate alınarak; bu faktöre 'Marka Ünü ' ismi verilmiştir. Bu faktörün açıklanan varyans yüzdesinin $\% 5,319$ olduğu tespit edilmiştir.

\section{Korelasyon Analizleri Sonuçları}

Korelasyon katsayısı bir oran olup, -1 ile +1 arasında bir değerdir. Katsayı pozitif ise, değişkenlerin biri artarken diğeri de artıyor; negatif ise, değişkenlerin biri artarken diğeri azalıyor demektir (Nakip, 2003: 322). 
Tablo 13: Korelasyon Katsayılarının İlişki Dereceleri

\begin{tabular}{|l|l|}
\hline Korelasyon Katsayısı (\%) & ilişki Derecesi \\
\hline 0 & ilişki yok \\
\hline $01-10$ & Çok zayıf \\
\hline $11-20$ & Nisbeten çok zayıf \\
\hline $21-30$ & Zayıf \\
\hline $31-40$ & Nisbeten zayıf \\
\hline $41-50$ & Çok az zayıf \\
\hline $51-60$ & Çok az güçlü \\
\hline $61-70$ & Nisbeten güçlü \\
\hline $71-80$ & Güçlü \\
\hline $81-90$ & $\begin{array}{l}\text { Nisbeten } \\
\text { güçlü }\end{array}$ \\
\hline $91-100$ & çok güçlü \\
\hline
\end{tabular}

Kaynak: Nakip, M., 2003, Ankara, Pazarlama Araştırmaları Teknikler ve (SPSS Destekli) Uygulamalar, İstanbul, Seçkin Yayıncılık San. Ve Tic. A.Ş., s. 322.

Yukarıdaki korelasyon katsayılarının ilişki derecelerini içeren Tablo.13 dikkate alınarak bu çalışmaya ait korelasyon analizleri değerlendirilmiştir.

Tablo 14: Lojistik Hizmet Performansı ile Marka Sadakati Arasındaki İlişki

\begin{tabular}{|l|r|l|l|}
\hline \multicolumn{2}{|l|}{} & $\begin{array}{l}\text { Lojistik } \\
\text { Hizmet } \\
\text { Performansı }\end{array}$ \\
\hline $\begin{array}{l}\text { Pearson } \\
\text { Korelasyon }\end{array}$ & Marka Sadakati & $\begin{array}{l}\text { Korelasyon } \\
\text { Katsayısı }\end{array}$ &, $505(* *)$ \\
\hline \multicolumn{2}{|c|}{ Anlamlılık Düzeyi } &, 000 \\
\hline
\end{tabular}

(**) Korelasyon, 0,01 düzeyinde anlamlıdır.

H0: Lojistik hizmet performansı ile marka sadakati arasında bir ilişki yoktur H1: Lojistik hizmet performansı ile marka sadakati arasında bir ilişki vardır. 
Analiz sonucuna göre, 0.000 anlamlılık düzeyinde, H0 reddedilerek, H1 hipotezimiz kabul edilmiştir. Lojistik hizmet performansı ile marka sadakati arasında anlamlı, pozitif yönlü ve çok az zayıf bir ilişki bulunduğu söylenebilir (Pearson Korelasyon Katsayısı: 0,505). Buna göre; e-ticaret sitelerinin lojistik hizmet performanslarının artması ile marka sadakati göstergelerinde de artış gözlemlenebileceği söylenebilir.

Tablo 15: Güven ile Marka Sadakati Arasında Arasındaki İlişki

\begin{tabular}{|l|r|l|r|}
\hline \multicolumn{2}{|c|}{} & Güven \\
\hline $\begin{array}{l}\text { Pearson } \\
\text { Korelasyon }\end{array}$ & Marka Sadakati & $\begin{array}{l}\text { Korelasyon } \\
\text { Katsayısı }\end{array}$ &, 000 \\
\hline \multicolumn{3}{|c|}{ Anlamlılık Düzeyi } \\
\hline
\end{tabular}

(**) Korelasyon, 0,01 düzeyinde anlamlıdır.

H0: Güven ile marka sadakati arasında bir ilişki yoktur

H2: Güven ile marka sadakati arasında bir ilişki vardır.

Analiz sonucuna göre, 0.000 anlamlılık düzeyinde, H0 reddedilerek, H2 hipotezimiz kabul edilmiştir. Güven ile marka sadakati arasında anlamlı, pozitif yönlü ve güçlü bir ilişki bulunduğu söylenebilir (Pearson Korelasyon Katsayısı: 0,802). Buna göre; e-ticaret sitelerine duyulan güvenin artması ile marka sadakati göstergelerinde de artış gözlemlenebileceği söylenebilir.

Tablo 16: Marka Tahminlemesi ile Marka Sadakati Arasındaki İlişki

\begin{tabular}{|l|r|l|r|}
\hline \multicolumn{2}{|l|}{} & $\begin{array}{l}\text { Marka } \\
\text { Tahminlemesi }\end{array}$ \\
\hline $\begin{array}{l}\text { Pearson } \\
\text { Korelasyon }\end{array}$ & Marka Sadakati & $\begin{array}{l}\text { Korelasyon } \\
\text { Katsayısı }\end{array}$ &, $675\left(^{* *}\right)$ \\
\hline \multicolumn{3}{|c|}{ Anlamlılık Düzeyi } &, 000 \\
\hline
\end{tabular}

${ }^{* *}$ Korelasyon, 0,01 düzeyinde anlamlıdır.

H0: Marka tahminlemesi ile marka sadakati arasında bir ilişki yoktur

H3: Marka tahminlemesi ile marka sadakati arasında bir ilişki vardır.

Analiz sonucuna göre, 0.000 anlamlılık düzeyinde, H0 reddedilerek, H3 hipotezimiz kabul edilmiştir. Marka tahminlemesi ile marka sadakati arasında anlamlı, pozitif yönlü ve nisbeten güçlü bir ilişki bulunduğu söylenebilir (Pearson Korelasyon Katsayısı: 0,675). Buna 
göre; tüketicilerin marka tahminlemesinin artması ile marka sadakati göstergelerinde de artış gözlemlenebileceği söylenebilir.

Tablo 17: Marka Ünü ile Marka Sadakati Arasındaki İlişki

\begin{tabular}{|l|r|l|r|}
\hline \multicolumn{2}{|c|}{} & Marka Ünü \\
\hline $\begin{array}{l}\text { Pearson } \\
\text { Korelasyon }\end{array}$ & Marka Sadakati & $\begin{array}{l}\text { Korelasyon } \\
\text { Katsayısı }\end{array}$ &, $399\left(^{* *}\right)$ \\
\hline \multicolumn{3}{|c|}{ Anlamlılık Düzeyi } &, 000 \\
\hline
\end{tabular}

$\left.{ }^{* *}\right)$ Korelasyon, 0,01 düzeyinde anlamlıdır.

H0: Marka ünü ile marka sadakati arasında bir ilişki yoktur

H4: Marka ünü ile marka sadakati arasında bir ilişki vardır.

Analiz sonucuna göre, 0.000 anlamlılık düzeyinde, H0 reddedilerek, H4 hipotezimiz kabul edilmiştir. Marka ünü ile marka sadakati arasında anlamlı, pozitif yönlü ve nisbeten zayıf bir ilişki bulunduğu söylenebilir (Pearson Korelasyon Katsayısı: 0,399). Buna göre; marka ününün artması ile marka sadakati göstergelerinde de artış gözlemlenebileceği söylenebilir.

\section{Sonuç}

Araştırma kapsamında yapılan korelasyon analizi sonucunda; e-ticaret sitelerinin marka sadakati oluşturma süreci ile lojistik hizmet düzeyi, marka ünü, marka tahminlemesi ve güven değişkenleri arasında anlamlı ilişkiler olduğu tespit edilmiştir. Buna göre; e-ticaret sitelerinin lojistik hizmet düzeyleri, tüketicinin güveni ve beklentilerini karşlayabilme oranları arttıkça; tüketicilerin e-ticaret sitesine sadakatinin de artacağı söylenebilir. Müşteri sadakati, işletme için uzun vadeli karlılık anlamına gelmekte olup; işletmenin finansal ve pazarlama performansı da olumlu yönde etkilemektedir. Yapılan bu çalışma sonucunda; eticaret sitelerinin lojistik hizmet performansı göstergeleri; siparişin durumu ve teslimat zamanı olarak iki ayrı faktöre ayrılmıştır. Araştırma örneklemi kapsamında, e-ticaret sitelerinin müşterilerine doğru siparişi, kısa ve istenilen zamanda, hasarsız bir şekilde teslim etmeleri müşteri sadakatine olumlu yönde etki yapacağı sonucuna varılabilmektedir. Yapılan bu çalışmada, müşterinin markaya duyduğu güvenin sadakatine katkı sağladığı sonucunun tespit edilmesi işletmeler açısından önemlidir. Bu çalışmanın sonuçlarının, eticaret siteleri ve işletmeler açısından müşteri sadakati yaratmaları konusunda ilgi çekici ipuçları taşıdığı düşünülmektedir.

\section{Kaynakça}

Aaker, D.A. (1996). Building Strong Brands. N.Y.: Simon \& Schuster Inc.

Arabacı, B. (2010). Müşteri Hizmetleri ve CRM. İstanbul: Kumsaati Yayın Dağıtım Ltd. Şti. 
Babalco, C., Gatej, C., Ciobanu, O. (2012). Developing a scale to measure customer loyalty. Procedia Economics and Finance, 3, 623-628.

Gegez, E. (2010). Pazarlama Araştırmaları. İstanbul: Beta Basım A.Ş..

Lau, G. T., Lee, S.H. (1999). Consumers' Trust in a brand and link to brand loyalty. Journal of Market Focused Management, 4, 341-370.

Huang, Y. K., Kuo, Y.W., Xu, S.W. (2009). Applying importance-performance analysis to evaluate logistics service quality for online shopping among retailing delivery. International Journal of Electronic Businesss Management, Vol.7, No.2, 128-136.

Matzler, K., Grabner-Krauter, S., Bidman, S. (2006). The value-Brand loyalty chain: an analysis of some moderating variables. Innovate Marketing,Vol. 2, Issue 2, 76-87.

Nakip, M. (2003). Pazarlama Araştırmaları Teknikler ve (SPSS Destekli) Uygulamalar. İstanbul: Seçkin Yayıncılık San. Ve Tic. A.Ş.

Naumann, E., Giel, K. (1995) , Customer Satisfaction Measurement And Management Using The Voice Of The Customer, Cincinnati: Thomson Executive Press.

Odabaşı, Y. (2010). Satışta ve Pazarlamada Müşteri İlişkileri Yönetimi. İstanbul : Sistem Yayıncılık.

Uztuğ, F. (2003). Markan Kadar Konuş Marka İletişimi Stratejileri, İstanbul: Kapital Medya Hizmetleri A:Ş..

Yeşil, .A. (2010). E-ticaret: İnternet Ortamında Ticaret. İstanbul : Kum Saati Yayın Dağıtım Ltd. Şti. 